\title{
HUBUNGAN LINGKAR LEHER DAN LINGKAR PINGGANG DENGAN KADAR TRIGLISERIDA ORANG DEWASA (STUDI KASUS DI SMA NEGERI 2 SEMARANG DAN SMP NEGERI 9 SEMARANG)
}

\author{
Rahma Teta Amelinda, Yekti Wirawanni* ${ }^{*}$ \\ Program Studi Ilmu Gizi Fakultas Kedokteran Universitas Diponegoro \\ J1.Dr.Sutomo No.18, Semarang, Telp (024) 8453708, Email : gizifk@ undip.ac.id
}

\begin{abstract}
Background : Hypertriglyceridemia is risk factor of metabolic syndrome and cardiovascular disease. Therefore, early prevention is needed. The prevention can be done by screening. Screening method that easy, inexpensive, and non-invasive was anthropometric. The anthropometric were neck circumference and waist circumference. The study aims to determine correlation between neck circumference, waist circumference, and triglyceride in adults.

Methods : The design of this study was cross-sectional study. The subjects of this study were 51 people (33 female and 18 male). They were employees that work in SMA Negeri 2 Semarang and SMP Negeri 9 Semarang. The subjects were $\geq 45$ years old. Characteristic of the subjects were collected by interviewing, while neck and waist circumference were collected using nonstrecthable tape. Besides, blood samples were also taken to measure triglyceride levels.

Result : The study showed that 25,5\% of the subjects had high neck circumference, 31,4\% of the subjects had high waist circumference, and 33,3\% of the subjects had high triglyceride. The result of this study indicates that neck circumference has a positive correlation with triglyceride levels $(r=0,540, p=0,000)$. The positive correlation was also seen on the waist circumference and triglyceride levels $(r=0,367, p=0,008)$. Both of them showed significant correlation with triglyceride levels $(p<0,05)$.

Conclusion: There is a significant correlation among neck circumference, waist circumference, and triglyceride levels. The increase of neck and waist circumference causes the increase of triglyceride levels.

Keyword : neck circumference; waist circumference; triglyceride
\end{abstract}

\begin{abstract}
ABSTRAK
Latar Belakang : Hipertrigliseridemia menjadi salah satu faktor risiko terjadinya sindrom metabolik dan penyakit kardiovaskuler. Oleh karena itu, pencegahan dini sangat diperlukan. Salah satu pencegahan yang dapat dilakukan yaitu dengan cara skrining. Metode skrining yang mudah dan murah serta tidak invasif adalah metode antropometri. Pengukuran antropometri tersebut antara lain lingkar leher dan lingkar pinggang. Penelitian ini bertujuan untuk mengetahui hubungan lingkar leher dan lingkar pinggang dengan kadar trigliserida orang dewasa. Metode : Jenis penelitian adalah observasional analitik dengan pendekatan cross sectional. Subjek penelitian ini sebanyak 51 orang yang terdiri dari 33 wanita dan 18 pria pegawai sekolah SMA Negeri 2 Semarang dan SMP Negeri 9 Semarang yang berusia $\geq 45$ tahun. Pengambilan data karakteristik subjek dilakukan dengan wawancara sedangkan lingkar leher dan lingkar pinggang menggunakan metline. Selain itu, dilakukan pengambilan sampel darah untuk pengukuran kadar trigliserida.

Hasil : Penelitian ini terdapat 25,5\% subjek mempunyai lingkar leher besar, 31,4\% mempunyai lingkar pinggang besar, dan 33,3\% mempunyai kadar trigliserida tinggi. Hasil penelitian menunjukkan bahwa lingkar leher memiliki hubungan yang positif dengan kadar trigliserida $(r=0,540, p=0,000)$. Korelasi yang positif juga terlihat pada lingkar leher dengan kadar trigliserida $(r=0,367, p=0,008)$. Keduanya menujukkan korelasi yang bermakna dengan kadar trigliserida $(p<0,05)$.

Simpulan : Terdapat hubungan yang bermakna antara lingkar leher dan lingkar pinggang dengan kadar trigliserida. Semakin besar lingkar leher dan lingkar pinggang maka semakin tinggi kadar trigliserida.
\end{abstract}

Kata Kunci : lingkar leher; lingkar pinggang; trigliserida

\section{PENDAHULUAN}

Trigliserida merupakan jenis lemak yang ada di dalam darah dan merupakan hasil uraian tubuh pada makanan yang mengandung lemak dan kolesterol. ${ }^{1}$ Berdasarkan The National Cholesterol Education Program Adult Treatment Panel III (NCEP, ATP III), rujukan kadar trigliserida normal yaitu $<150 \mathrm{mg} / \mathrm{dL}^{2}{ }^{2}$ Dalam keadaan normal, trigliserida digunakan tubuh sebagai sumber energi bagi berbagai proses metabolik. Selain itu trigliserida juga digunakan untuk membentuk membran sel. ${ }^{1}$

Kadar trigliserida yang berlebih dalam tubuh disebut hipertrigliseridemia. ${ }^{3}$ Kondisi hipertrigliseridemia dapat disebabkan karena tingginya kadar asam lemak bebas di sirkulasi yang dilepaskan oleh jaringan adiposa. ${ }^{4}$ Hipertrigliseridemia ini menjadi salah satu faktor 
risiko terjadinya sindrom metabolik dan penyakit kardiovaskuler. ${ }^{5}$ Faktor risiko lain terjadinya sindrom metabolik dan penyakit kardiovaskuler yaitu usia. Usia merupakan faktor risiko penyakit kardiovaskuler yang tidak dapat dimodifikasi. Semakin bertambahnya usia akan terjadi penurunan fungsi metabolisme yang dapat meningkatkan risiko terjadinya sindrom metabolik serta penyakit kardiovaskuler. ${ }^{6}$ Pada penelitian di Bogor didapatkan faktor risiko sindroma metabolik menjadi 2 kali lipat lebih banyak pada usia 44 tahun ke atas, dibandingkan usia di bawahnya. ${ }^{7}$

Prevalensi hipertrigliseridemia yang cukup tinggi dapat diketahui dari hasil penelitian pada penduduk desa di Bali dengan subjek pria dan wanita usia $\geq 18$ tahun yaitu sebesar $38,4 \% .{ }^{8}$ Selain itu penelitian dengan subjek lansia di perkotaan diketahui prevalensi hipertrigliseridemia sebesar 21,7\%.9 Penelitian di Semarang menunjukkan bahwa individu yang memiliki kadar trigliserida $\geq 150 \mathrm{mg} / \mathrm{dl}$ mengalami peningkatan risiko terjadinya penyakit jantung koroner sebesar 2,8 kali dibandingkan dengan individu yang kadar trigliseridanya $<150 \quad \mathrm{mg} / \mathrm{dl}^{10} \quad$ Berdasarkan penelitian meta-analisis terhadap ratusan pasien selama 10 tahun menunjukkan bahwa kadar trigliserida yang meningkat sebanyak $1 \mathrm{mmol} / \mathrm{L}$ dapat meningkatkan risiko penyakit kardiovaskuler sebesar 32\% pada laki-laki dan $76 \%$ pada wanita. ${ }^{11}$

Keadaan hipertrigliseridemia ini dapat meningkatkan angka morbiditas dan mortalitas. Oleh karena itu, pencegahan dini sangat diperlukan. Salah satu pencegahan yang dapat dilakukan yaitu dengan cara skrining. Metode skrining yang mudah dan murah serta tidak invasif adalah metode antropometri. ${ }^{12}$ Pengukuran antropometri tersebut antara lain lingkar pinggang dan lingkar leher. Keduanya merupakan indeks obesitas tubuh bagian atas atau upper body obesity. ${ }^{13}$

Lingkar pinggang menggambarkan lemak viseral atau obesitas sentral. Selama ini diketahui bahwa obesitas sentral berhubungan dengan sindrom metabolik yang salah satunya yaitu peningkatan kadar trigliserida sebagai faktor risiko penyakit kardiovaskuler. Kelebihan lemak pada perut ini meningkatkan produksi asam lemak bebas yang dapat meningkatkan kadar trigliserida, sehingga menyebabkan hipertrigliseridemia. ${ }^{14}$ Namun, pada penelitian mengenai lingkar leher menyatakan bahwa leher merupakan depot lemak subkutan dianggap sebagai parameter yang lebih baik dalam mengetahui risiko penyakit kardiovaskuler dibandingkan dengan lemak bagian viseral. Hal ini dikarenakan lemak viseral bukan merupakan sumber yang utama dalam melepaskan asam lemak bebas. ${ }^{15,16}$

Penelitian di Indonesia mengenai hubungan lingkar pinggang dengan kadar trigliserida sudah pernah dilakukan. Subjek yang digunakan yaitu pasien rawat jalan dengan dislipidemia. Hasil penelitian tersebut menunjukkan ada hubungan antara keduanya. ${ }^{12}$ Namun, di Indonesia penelitian mengenai hubungan lingkar leher dan lingkar pinggang dengan kadar trigliserida pada individu yang sehat masih belum dilakukan. Berdasarkan latar belakang tersebut, maka perlu diketahui hubungan lingkar leher dan lingkar pinggang sebagai indeks distribusi lemak tubuh bagian atas dengan kadar trigliserida pada orang dewasa.

\section{METODE}

Penelitian ini merupakan penelitian observasional analitik dengan pendekatan cross sectional yang dilaksanakan di SMA Negeri 2 Semarang dan SMP Negeri 9 Semarang.. Ruang lingkup penelitian ini termasuk ke dalam bidang gizi masyarakat. Populasi target yaitu seluruh penduduk di kota Semarang. Populasi terjangkau yaitu seluruh pegawai sekolah usia $\geq 45$ tahun di SMA Negeri 2 Semarang dan SMP Negeri 9 Semarang. Jumlah subjek dalam penelitian ini sebanyak 51 orang yang terdiri dari 33 wanita dan 18 pria. Subjek dipilih menggunakan teknik consecutive sampling. Kriteria inklusi subjek penelitian ini yaitu sampel berjenis kelamin lakilaki dan perempuan dengan usia $\geq 45$ tahun, tidak sedang mengonsumsi obat penurun lipid (selama 3 hari sebelum pengambilan sampel darah), tidak sedang mengalami penyakit gondok (goiter disease), tumor tiroid, pembesaran kelenjar getah bening, tidak terdapat kelainan pada leher yang dapat mengganggu pengukuran lingkar leher, tidak sedang hamil, tidak mengalami oedem anasarka dan asites, serta bersedia menjadi subjek penelitian. Sedangkan kriteria eksklusi yaitu tidak datang pada saat pengambilan sampel darah dan subjek mengundurkan diri dari penelitian.

Variabel bebas dalam penelitian ini adalah lingkar leher dan lingkar pinggang. Variabel terikat adalah kadar trigliserida. Data yang dikumpulkan meliputi nama, usia, jenis kelamin, berat badan, tinggi badan, ada/tidaknya riwayat penyakit, ada/tidaknya riwayat mengonsumsi obat penurun lipid, lingkar leher, lingkar pinggang, dan kadar trigliserida.

Lingkar leher diukur menggunakan pita metline dengan posisi berdiri tegak, tenang, dan menghadap lurus ke depan, pengukuran lingkar 
leher pada subjek perempuan terletak di bagian tengah leher di antara spina servikalis media (mid cervicalis spine) sampai bagian tengah leher depan (mid anterior neck). Sedangkan pada laki-laki pengukuran lingkar leher tepat di bawah laryngeal prominience (Apple's Adam) atau tulang rawan tiroid. ${ }^{17}$ Hasil pengukuran lingkar leher dengan satuan sentimeter $(\mathrm{cm})$ dan skala rasio. Kategori lingkar leher dibagi menjadi 3 yaitu kecil (pria <35 $\mathrm{cm}$, wanita $<31 \mathrm{~cm}$ ), sedang (pria $35-38 \mathrm{~cm}$, wanita 31-34 cm), dan besar (pria $>38 \mathrm{~cm}$, wanita $>34 \mathrm{~cm}$ ). Sedangkan pada pengukuran lingkar pinggang dilakukan dalam posisi berdiri tegak dan tenang dengan tungkai dilebarkan $20-30 \mathrm{~cm}$, serta baju atau penghalang pengukuran disingkirkan. Lingkar pinggang diukur dengan metline yang diletakkan secara horizontal dan melingkar pada kulit di daerah abdomen tanpa alas kain dengan patokan titik tengah antara kosta terakhir dengan krista iliaka. Pengukuran lingkar pinggang ini, abdomen harus alam keadaan rileks dan pengukuran dilakukan pada saat akhir ekspirasi. Hasil pengukuran lingkar pinggang dengan satuan sentimeter $(\mathrm{cm})$ dan skala rasio. Kategori lingkar pinggang dibagi menjadi 3 yaitu kecil (pria $<81$ $\mathrm{cm}$, wanita $<82 \mathrm{~cm}$ ), sedang (pria $81-94 \mathrm{~cm}$, wanita $82-93 \mathrm{~cm}$ ), dan besar (pria $>94 \mathrm{~cm}$, wanita $>93 \mathrm{~cm}$ ). Pengukuran lingkar leher dan lingkar pinggang dilakukan sebanyak 3 kali oleh petugas yang sudah terlatih. Data lingkar leher dan lingkar pinggang yang diambil adalah hasil rerata dari 3 kali pengukuran.

Pengukuran kadar trigliserida darah subjek penelitian dilakukan oleh petugas Laboratorium Permata Semarang yang diambil melalui pembuluh darah vena setelah sebelumnya subjek melakukan puasa minimal 8-12 jam. Pengukuran kadar trigliserida menggunakan alat spekofotometri dengan hasil pengukuran dalam satuan $\mathrm{mg} / \mathrm{dl}$ dan berskala rasio. Batas normal kadar trigliserida berdasarkan The National Cholesterol Education Program Adult Treatment Panel III (NCEP, ATP III) yaitu $<150 \mathrm{mg} / \mathrm{dl} .^{2}$

Analisis data menggunakan software SPSS 17.0 for windows. Analisis univariat dilakukan untuk mendeskripsikan data karakteristik subjek, seperti usia, IMT, jenis kelamin, lingkar leher, lingkar pinggang, dan kadar trigliserida. Sebaran data dapt diketahui normalitasnya melalui uji Kolmogorov Smirnov dengan nilai kemaknaan p > 0,05 untuk sampel lebih dari 50 responden. Uji yang digunakan untuk mengetahui hubungan lingkar leher dan lingkar pinggang dengan kadar trigliserida yaitu menggunakan uji korelasi Pearson karena data berdistribusi normal.

\section{HASIL PENELITIAN \\ Karakteristik Subjek}

Jumlah subjek penelitian ini adalah sebesar 51 orang yang berasal dari suku Jawa. Subjek penelitian terdiri dari 18 orang pria dan 33 orang wanita. Sebagian besar subjek penelitian memiliki IMT $\geq 25 \mathrm{~kg} / \mathrm{m}^{2}$ yaitu sebanyak 41 orang $(80,4 \%)$. Subjek yang memiliki kadar trigliserida tinggi sebanyak 17 orang $(33,3 \%)$. Usia subjek penelitian berkisar 45 sampai 60 tahun. Rerata usia pada subjek pria dan wanita dapat dikatakan tidak ada perbedaan. Hal ini juga terlihat pada variabel lingkar pinggang dan kadar trigliserida yang reratanya tidak jauh berbeda antara subjek pria dan wanita. Sedangkan pada variabel lainnya menunjukkan ada perbedaan rerata antara subjek pria dan wanita. Karakteristik subjek penelitian dapat dilihat pada tabel 1 dan 2.

Tabel 1. Distribusi Subjek Penelitian Berdasarkan Jenis Kelamin dan IMT

\begin{tabular}{lcc}
\hline \multicolumn{1}{c}{ Variabel } & Frekuensi & Persentase \\
\hline Jenis kelamin & & \\
Pria & 18 & $35,3 \%$ \\
Wanita & 33 & $64,7 \%$ \\
\hline IMT $\left(\mathbf{k g} / \mathbf{m}^{\mathbf{2}}\right)$ & & \\
Normal $: 18,5-22,9$ & 4 & $7,8 \%$ \\
Overweight $: 23-24,9$ & 6 & $11,8 \%$ \\
Obese $: \geq 25$ & 41 & $80,4 \%$ \\
\hline Kadar Trigliserida (mg/dl) & & \\
Normal : 150 & 34 & $66,7 \%$ \\
Tinggi $: \geq 150$ & 17 & $33,3 \%$ \\
\hline
\end{tabular}

Tabel 2. Karakteristik Subjek Penelitian Berdasarkan Usia, IMT, Lingkar Leher, Lingkar Pinggang, dan Kadar Trigliserida

\begin{tabular}{|c|c|c|c|c|c|c|c|c|}
\hline & \multicolumn{4}{|c|}{ Pria $(n=18)$} & \multicolumn{4}{|c|}{ Wanita $(n=33)$} \\
\hline & Min & Max & Median & Rerata $\pm \mathrm{SD}$ & Min & Max & Median & Rerata \pm SD \\
\hline Usia & 48 & 60 & 52,5 & $52,8 \pm 3,2$ & 45 & 60 & 53 & $52,8 \pm 4,1$ \\
\hline
\end{tabular}




\begin{tabular}{lcccccccc} 
IMT * $^{*}$ & 20,8 & 30,3 & 25,6 & $25,7 \pm 2,4$ & 20,1 & 33,1 & 28,4 & $27,9 \pm 3,1$ \\
Lingkar leher & 34 & 41,6 & 37 & $37,2 \pm 2,0$ & 28,3 & 35,3 & 33 & $32,6 \pm 1,8$ \\
Lingkar pinggang & 69,5 & 102,5 & 90,5 & $88,3 \pm 9,2$ & 74,3 & 108,6 & 89,5 & $90,1 \pm 7,2$ \\
Kadar trigliserida & 82 & 260 & 14,5 & $155,7 \pm 54,2$ & 58 & 288 & 126 & $130,3 \pm 50,5$ \\
\hline
\end{tabular}

*bermakna dengan $\mathrm{p}<0,05$

Berdasarkan nilai rerata dan nilai distribusi masing-masing berdasarkan kategori simpangan baku di atas, lingkar leher dan lingkar kadar trigliserida. Data distribusi variabel tersebut pinggang dibagi menjadi 3 kategori untuk melihat dapat dilihat pada tabel 3,4,5, dan 6 .

Tabel 3. Distribusi Lingkar Leher Berdasarkan Kadar Trigliserida pada Subjek Pria

\begin{tabular}{clccc}
\hline & & \multicolumn{2}{c}{ Kadar trigliserida $(\mathrm{mg} / \mathrm{dl})$} & \multirow{2}{*}{ Total } \\
\cline { 3 - 4 } & & $\begin{array}{c}\text { normal } \\
\mathrm{n}(\%)\end{array}$ & $\begin{array}{c}\text { Tinggi } \\
\mathrm{n}(\%)\end{array}$ & \\
\hline \multirow{2}{*}{$\begin{array}{c}\text { Lingkar leher } \\
(\mathrm{cm})\end{array}$} & 355 & $3(100 \%)$ & $0(0 \%)$ & $3(100 \%)$ \\
& $>38$ & $7(70 \%)$ & $3(30 \%)$ & $10(100 \%)$ \\
& $0(0 \%)$ & $5(100 \%)$ & $5(100 \%)$ \\
\hline
\end{tabular}

Tabel 4. Distribusi Lingkar Leher Berdasarkan Kadar Trigliserida pada Subjek Wanita

\begin{tabular}{clccc}
\hline & & \multicolumn{2}{c}{ Kadar trigliserida $(\mathrm{mg} / \mathrm{dl})$} & \multirow{2}{*}{ Total } \\
\cline { 3 - 4 } & & $\begin{array}{c}\text { normal } \\
\mathrm{n}(\%)\end{array}$ & $\begin{array}{c}\text { tinggi } \\
\mathrm{n}(\%)\end{array}$ & \\
\hline \multirow{2}{*}{$\begin{array}{c}\text { Lingkar leher } \\
(\mathrm{cm})\end{array}$} & $31-35$ & $7(100 \%)$ & $0(0 \%)$ & $7(100 \%)$ \\
& $>35$ & $17(68 \%)$ & $8(32 \%)$ & $18(100 \%)$ \\
& & $0(0 \%)$ & $1(100 \%)$ & $8(100 \%)$ \\
\hline
\end{tabular}

Berdasarkan tabel 3, sebanyak 30\% subjek pria dengan lingkar leher $35-38 \mathrm{~cm}$ memiliki kadar trigliserida yang tinggi dan pada kategori lingkar leher $>38 \mathrm{~cm}$ subjek yang memiliki kadar trigliserida tinggi meningkat menjadi $100 \%$. Sedangkan pada subjek wanita (tabel 4), sebanyak $32 \%$ subjek wanita dengan lingkar leher $31-35 \mathrm{~cm}$

memiliki kadar trigliserida yang tinggi dan pada subjek dengan lingkar leher $>34 \mathrm{~cm}$ yang memiliki kadar trigliserida tinggi mengalami peningkatan menjadi $100 \%$. Secara keseluruhan jumlah subjek yang mempunyai lingkar leher besar (pria $>38 \mathrm{~cm}$ dan wanita $>35 \mathrm{~cm}$ ) adalah sebanyak 6 orang $(11,8 \%)$.

Tabel 5. Distribusi Lingkar Pinggang Berdasarkan Kadar Trigliserida pada Subjek Pria

\begin{tabular}{clccc}
\hline & & \multicolumn{2}{c}{ Kadar trigliserida $(\mathrm{mg} / \mathrm{dl})$} & \multirow{2}{*}{ Total } \\
\cline { 2 - 4 } & & $\begin{array}{c}\text { normal } \\
\mathrm{n}(\%)\end{array}$ & $\begin{array}{c}\text { tinggi } \\
\mathrm{n}(\%)\end{array}$ & \\
\hline \multirow{2}{*}{ Lingkar } & $<81$ & $3(100 \%)$ & $0(0 \%)$ & $3(100 \%)$ \\
pinggang $(\mathrm{cm})$ & $81-101$ & $7(50 \%)$ & $7(50 \%)$ & $11(100 \%)$ \\
& $>101$ & $0(0 \%)$ & $1(100 \%)$ & $4(100 \%)$ \\
\hline
\end{tabular}

Tabel 6. Distribusi Lingkar Pinggang Berdasarkan Kadar Trigliserida pada Subjek Wanita

\begin{tabular}{clccc}
\hline & & \multicolumn{2}{c}{ Kadar trigliserida $(\mathrm{mg} / \mathrm{dl})$} & \multirow{2}{*}{ Total } \\
\cline { 3 - 4 } & & $\begin{array}{c}\text { normal } \\
\mathrm{n}(\%)\end{array}$ & $\begin{array}{c}\text { tinggi } \\
\mathrm{n}(\%)\end{array}$ & \\
\hline \multirow{2}{*}{ Lingkar } & $<82$ & $4(100 \%)$ & $0(0 \%)$ & $4(100 \%)$ \\
pinggang $(\mathrm{cm})$ & $82-101$ & $20(71,4 \%)$ & $8(28,6 \%)$ & $17(100 \%)$ \\
& $>101$ & $0(0 \%)$ & $1(100 \%)$ & $12(100 \%)$ \\
\hline
\end{tabular}


Berdasarkan tabel 5, sebanyak 50\% subjek pria dengan lingkar pinggang $81-101 \mathrm{~cm}$ memiliki kadar trigliserida yang tinggi dan sebanyak $100 \%$ subjek pria dengan lingkar pinggang $>101 \mathrm{~cm}$ juga memiliki kadar trigliserida yang tinggi. Sedangkan sebanyak 28,6\% pada subjek wanita (tabel 6) dengan lingkar pinggang 82-101 cm memiliki kadar trigliserida yang tinggi dan sebanyak $100 \%$ subjek wanita dengan lingkar pinggang $>101 \mathrm{~cm}$ memiliki kadar trigliserida yang tinggi. Secara keseluruhan jumlah subjek yang mempunyai lingkar pinggang besar (pria $>101 \mathrm{~cm}$ dan wanita $>101 \mathrm{~cm})$ adalah sebanyak 2 orang $(3,9 \%)$.

\section{Hubungan Lingkar Leher dan Lingkar Pinggang dengan Kadar Trigliserida}

Berdasarkan tabel 6, hubungan lingkar leher dengan kadar trigliserida memiliki nilai korelasi 0,540 dengan nilai kemaknaan 0,000. Hal ini menunjukkan bahwa secara statistika ada korelasi yang bermakna antara lingkar leher dengan kadar trigliserida karena $\mathrm{p}<0,05$. Nilai korelasi yang positif antara dua variabel tersebut menunjukkan hubungan yang searah.

Sedangkan lingkar pinggang dengan kadar trigliserida memiliki nilai korelasi 0,367 dengan nilai kemaknaan 0,008. Hal ini menunjukkan bahwa korelasi antara lingkar pinggang dengan kadar trigliserida juga bermakna secara statistika karena $\mathrm{p}<0,05$. Nilai korelasi lingkar pinggang juga menunjukkan hubungan yang searah dengan kadar trigliserida.

Tabel 6. Hubungan Lingkar Leher dan Lingkar Pinggang dengan Kadar Trigliserida

\begin{tabular}{ccccccc}
\hline & \multicolumn{2}{c}{ Lingkar leher } & & \multicolumn{2}{c}{ Lingkar pinggang } \\
\cline { 2 - 3 } \cline { 5 - 6 } \cline { 5 - 6 } Kadar trigliserida & $\mathrm{r}$ & $\mathrm{p}$ & & $\mathrm{r}$ & $\mathrm{P}$ \\
\hline
\end{tabular}

\section{PEMBAHASAN}

\section{Karakteristik Subjek}

Seluruh subjek penelitian ini berasal dari suku Jawa. Suku Jawa dapat mewakili ciri ras Mongoloid yang ada di Indonesia sehingga secara anatomis seluruh subjek penelitian memiliki kemiripan fisik. ${ }^{18}$

Sebagian besar subjek penelitian memiliki IMT $\geq 25 \mathrm{~kg} / \mathrm{m}^{2}$ yang berarti memiliki status gizi dengan kategori obesitas $(80,4 \%)$. IMT yang masuk dalam kategori obesitas juga merupakan salah satu faktor risiko meningkatkan kejadian hipertrigliseridemia yang mengarah pada penyakit kardiovaskuler. Semakin besar IMT seseorang, maka kadar trigliserida juga dapat meningkat. Hal ini sesuai dengan sebuah studi di Israel yang menyatakan adanya peningkatan kadar trigliserida seiring dengan peningkatan IMT. ${ }^{19}$

\section{Lingkar Leher}

Rerata lingkar leher pria lebih besar dari wanita. Hasil penelitian ini sesuai dengan beberapa penelitian yang menunjukkan bahwa rata-rata lingkar leher pada pria lebih besar dari wanita dan cut off point pria yang lebih besar dari wanita. ${ }^{20,21}$ Hal ini dapat dikarenakan pada pria memiliki dimensi fisik yang lebih besar dari wanita terutama pada saat dewasa. Pria memiliki dimensi fisik ratarata $7-10 \%$ lebih besar dari wanita. ${ }^{22}$

Lingkar leher sebesar $35-38 \mathrm{~cm}$ pada pria dan $31-35 \mathrm{~cm}$ pada wanita mulai menunjukkan adanya risiko individu tersebut memiliki kadar trigliserida yang tinggi $(\geq 150 \mathrm{mg} / \mathrm{dl})$. Risiko memiliki kadar trigliserida tinggi terlihat semakin meningkat pada subjek dengan lingkar leher $>38$ $\mathrm{cm}$ pada pria dan $>35 \mathrm{~cm}$ pada wanita. Hal ini sesuai dengan penelitian lingkar leher di China yang memiliki cut off point $\geq 37 \mathrm{~cm}$ untuk pria dan $\geq 33 \mathrm{~cm}$ untuk wanita. Penelitian di China menjelaskan bahwa individu yang memiliki lingkar leher melebihi cut off point tersebut berisiko mengalami peningkatan kadar trigliserida yang dapat mengarah pada sindrom metabolik dan penyakit kardiovaskuler. ${ }^{23}$

\section{Lingkar Pinggang}

Rerata lingkar pinggang pada penelitian ini menunjukkan bahwa lingkar pinggang pada wanita lebih besar dari pria. Hal ini sesuai dengan sebuah penelitian di Palembang dengan subjek usia $\geq 45$ tahun menunjukkan bahwa rerata lingkar pinggang wanita lebih besar dari pria. ${ }^{24}$ Hal ini dapat dikarenakan terjadinya penurunan massa bebas lemak (fat free mass) yang lebih besar pada wanita daripada pria. ${ }^{25}$

Data distribusi lingkar pinggang juga menunjukkan adanya peningkatan risiko memiliki kadar trigliserida tinggi pada tiap kategori lingkar pinggang. Lingkar pinggang sebesar $81-101 \mathrm{~cm}$ pada pria dan $82-101 \mathrm{~cm}$ pada wanita mulai menunjukkan adanya risiko memiliki kadar trigliserida tinggi. Risiko ini semakin meningkat 
pada kategori lingkar leher $>101 \mathrm{~cm}$ untuk pria maupun wanita. Hal ini sesuai dengan cut off point lingkar pinggang untuk orang Asia yang ditetapkan oleh Internasional Diabetes Federation (IDF) yaitu $\geq 90 \mathrm{~cm}$ untuk pria dan $\geq 80 \mathrm{~cm}$ untuk wanita. ${ }^{26}$ Lingkar pinggang yang melebihi batas normal dapat meningkatkan risiko hipertrigliseridemia yang berkaitan dengan penyakit kardiovaskuler. ${ }^{13}$

\section{Kadar Trigliserida}

Berdasarkan The National Cholesterol Education Program Adult Treatment Panel III (NCEP, ATP III), rujukan kadar trigliserida normal yaitu $<150 \mathrm{mg} / \mathrm{dL}^{2}$ Hasil penelitian ini menunjukkan bahwa subjek pria memiliki rerata kadar trigliserida yang lebih tinggi bila dibandingkan dengan wanita. Hasil ini hampir sama dengan penelitian di Palembang pada kelompok usia 55 tahun (trigliserida pria $=194,2$ $\mathrm{mg} / \mathrm{dl}$; wanita $=180,6 \mathrm{mg} / \mathrm{dl}$ ) dan penelitian di Turki dengan subjek rata-rata usia 54 tahun (trigliserida pria $=186 \mathrm{mg} / \mathrm{dl}$; $\quad$ wanita $=179$ $\mathrm{mg} / \mathrm{dl}){ }^{24,27}$

Rerata kadar trigliserida pada wanita masuk ke dalam kategori normal. Namun, rerata IMT pada wanita justru termasuk dalam kategori obesitas. Hal ini tidak sesuai dengan teori yang menyatakan bahwa orang yang obesitas mempunyai kadar trigliserida yang tinggi dalam plasma. Hal ini dapat dikarenakan trigliserida banyak tersimpan di bawah lipatan kulit. Semakin gemuk seseorang, semakin banyak trigliserida yang terdapat dalam tubuhnya dan menyebabkan lipatan-lipatan kulit. Walaupun trigliserida banyak disimpan di bawah lipatan kulit, tetapi tidak selalu membuat trigliserida di dalam darah menjadi tinggi. Simpanan trigliserida yang berlebih itu sewaktu-waktu berpotensi sebagai bahan pembentukan VLDL dan LDL di hepar. ${ }^{28}$

\section{Hubungan Lingkar Leher dan Lingkar Pinggang dengan Kadar Trigliserida}

Hasil penelitian ini menunjukkan bahwa ada hubungan antara lingkar leher dengan kadar trigliserida $(r=0,540, p<0,05)$. Pengukuran lingkar pinggang juga menunjukkan ada hubungan dengan kadar trigliserida $(r=0,367, p<0,05)$. Keduanya memiliki nilai korelasi yang bermakna. Hasil ini sesuai dengan penelitian di Belgaum dengan subjek orang dewasa yang rata-rata usianya 54 tahun. Penelitian tersebut menunjukkan adanya hubungan antara lingkar leher dengan kadar trigliserida $(\mathrm{r}=0,308, \mathrm{p}<0,005) .{ }^{29}$ Sedangkan adanya hubungan antara lingkar pinggang dengan kadar trigliserida pada penelitian ini sesuai dengan penelitian di Malang dengan rata-rata usia subjek yaitu 48 tahun yang juga menunjukkan adanya korelasi antara lingkar pinggang dengan kadar trigliserida $(r=0,686, p<0,1) .{ }^{12}$

Lingkar leher merupakan salah satu indeks distribusi lemak tubuh bagian atas atau upper body obesity. Kelebihan dari indeks lingkar leher terbukti memiliki kesalahan yang kecil dibandingkan indeks parameter lainnya serta dapat digunakan sebagai skrining obesitas yang mudah dan murah. ${ }^{30,31}$ Lingkar leher juga dapat digunakan sebagai prediktor adanya risiko penyakit kardiovaskuler. Mekanisme antara lingkar leher dengan risiko penyakit kardiovaskuler masih belum dapat diketahui secara pasti. Namun, aktivitas lipolisis lemak tubuh bagian atas mungkin menjadi salah satu mekanisme yang menjelaskan hubungan antara lingkar leher dengan risiko penyakit kardiovaskuler. Bagian leher yang merupakan lemak subkutan tubuh bagian atas berperan dalam melepaskan asam lemak bebas. Apabila terjadi peningkatan asam lemak bebas yang berlebih, maka dapat memicu meningkatnya kadar trigliserida dalam darah. Peningkatan kadar trigliserida inilah yang menjadi faktor risiko penyakit kardiovaskuler. Selain itu, hipertrigliseridemia juga menyebabkan trombosis arteri koroner yang dapat mengarah pada penyakit jantung koroner. ${ }^{5}$

Selain lingkar leher, hasil penelitian ini menunjukkan bahwa lingkar pinggang juga berhubungan positif dengan kadar trigliserida. Lingkar pinggang juga merupakan indeks upper body obesity yang dapat digunakan untuk menentukan obesitas sentral dan komplikasi metabolik yang terkait. Kriteria ukuran lingkar pinggang untuk etnis Asia yaitu kelompok laki-laki $\geq 90 \mathrm{~cm}$, sedangkan kelompok perempuan $\geq 80 \mathrm{~cm}$ dapat dikatakan beresiko komplikasi metabolik salah satunya hipertrigliseridemia. ${ }^{12}$ Individu dengan obesitas mengalami peningkatan total lemak tubuh. Simpanan lemak tubuh tersebut dapat terjadi di lemak subkutan (obesitas general) dan lemak viseral (obesitas sentral). Lemak viseral banyak terdapat dalam rongga perut yang dapat diketahui dari lingkar pinggang. Lemak ini memiliki adiposit yang berukuran besar yaitu adanya penimbunan jaringan lemak trigliserida yang menyebabkan peningkatan lipolisis dengan mudah, sehingga terjadi peningkatan asam lemak bebas. Peningkatan asam lemak bebas inilah yang dapat memicu hipertrigliseridemia. ${ }^{32}$

Berdasarkan hasil penelitian ini, diketahui bahwa nilai korelasi antara lingkar leher dengan 
kadar trigliserida lebih besar dari lingkar pinggang dengan kadar trigliserida. Berdasarkan nilai korelasi tersebut mengartikan bahwa lingkar leher merupakan indeks yang lebih baik dari lingkar pinggang. Penelitian di China juga menyatakan bahwa lingkar leher merupakan parameter yang lebih baik dari lingkar pinggang. ${ }^{33} \mathrm{Hal}$ ini mungkin dikarenakan leher yang merupakan bagian subkutan tubuh bagian atas melepaskan asam lemak bebas yang lebih besar dibandingkan dengan bagian viseral, terutama pada individu dengan obesitas. $^{34,35}$ Walaupun lemak subkutan tubuh bagian atas merupakan sumber utama asam lemak bebas pada individu obesitas, lipolisis jaringan lemak viseral juga berperan dalam peningkatan asam lemak bebas sehingga terjadi peningkatan kadar trigliserida. ${ }^{36}$

\section{SIMPULAN}

Terdapat hubungan yang bermakna antara lingkar leher dan lingkar pinggang dengan kadar trigliserida. Semakin besar lingkar leher, maka semakin tinggi kadar trigliserida. Hal ini juga berlaku pada lingkar pinggang yang semakin besar, maka kadar trigliseridanya juga semakin tinggi.

\section{SARAN}

Perlu dilakukan penelitian mengenai lingkar leher pada berbagai macam ras yang ada di Indonesia untuk mendapatkan cut off point sehingga hasilnya dapat digeneralisasikan secara umum pada masyarakat Indonesia.

\section{DAFTAR PUSTAKA}

1. Guyton AC, Hall JE. Metabolisme lipid dalam Buku Ajar Fisiologi Kedokteran. Edisi 11. 2008. Jakarta: EGC. p.882-894.

2. Houston CM, Egan BM. Metabolic Syndrome . The Journal of The American Nutraceutical Association. Vol 8, No 2.2005.

3. Pejic, Rade $\mathrm{N}$ and Daniel $\mathrm{T}$ Lee. Hypertriglyceridemia. JABFM. Vol 19 , No 3 . 2006.

4. Rader DJ, Hobbs HH. Disorders of lipoprotein metabolism. Harrison's Principles of Internal Medicine. 16th ed. New York: McGraw-Hill; 2005. p. 2286-98.

5. John D, Brunzell MD. Hypertriglyceridemia. $N$ Engl J Med 2007; 357: 1009-17.

6. Roy H, Lundy S, Kalicky B. Metabolic Syndrome, Pennington Nutrition Series,. Pub no .35. From URL: http://www.pbrc.edu/training-andeducation/ pdf/pns/ PNS_Metabolic_Syndrome.pdf

7. Lechleitner M. Obesity and Metabolic Syndrome in the Elderly: a Mini review. Gerontology. 2008; 54: 253-9.

8. Ayu, Paramita, Yenny Kandarini, G Raka Widiana, W Sudhana, Jodhi S Loekman, K
Suwitra. Prevalensi dan hubungan sindrom metabolik dengan penyakit ginjal kronik pada populasi Desa Legian, Kuta Bali. J Peny Dalam. Vol 12, No 2. 2011.

9. Ellya RD, Sijani P, Utju R, dan Edhiwan P. Dislipidemia pada kelompok usia lanjut di Lembang Bandung. JKM. Vol 1, No1. 2001.

10. Supriyono, M., Soeharyo Hadisaputro, Dugiri, Ari Udiyono, \& M. Sakundarno Adi. Faktor-faktor risiko kejadian Penyakit Jantung Koroner (PJK) pada kelompok Usia $\leq 45$ tahun. Program Magister Epidemiologi Program Pascasarjana Universitas Diponegoro.

11. Sulistyowati. Pemanfaatan yoghurt sebagai bahan penurun trigliserida darah manusia. Biologi FMIPA - Universitas PGRI Adi Buana Surabaya. Wahana Vol 51 No 2. 2008.

12. Riska, Dian. Hubungan lingkar pinggang dengan kadar trigliserida pada pasien rawat jalan dislipidemia di Puskesmas Janti Kota Malang. Jurusan Gizi Fakultas Kedokteran Universitas Brawijaya.

13. Boivin, Brochu, Marceau P. 2007. Regional differences in adipose tissue metabolism in obese men. Metabolism. 56:533-540.

14. Lakka HM., Laaksonen DE, Lakka TA, Niskanen LK, Kumpusalo E, Tuomilehto J. et.al. Disease mortality in middle-aged men the metabolic syndrome and total and cardiovascular. JAMA. 2002; 288(21):2709:2716.

15. Onat A, Hergenc G, Yuksel H, Can G, Ayhan E, Kaya Z. Neck circumference as a measure of central obesity: Associations with metabolic syndrome and obstructive sleep apnea syndrome beyond waist circumference. Clin Nutr 2009;28:46-51.

16. Ebbert, Jon $\mathrm{O}$ and Michael D Jensen. Fat depot, free fatty acids, and dyslipidemia. Nutrients 2013;5:498-508.

17. Mazicioglu, Muntaz M, S. Kurtoglu, Oztruk A. Percentiles and Mean Values for Neck Circumference in Turkish Children aged 6-18 years. Acta Pediatr. 2010. 99: 1847-1853.

18. Bellwood, Peter. 2000. Prasejarah Kepulauan Indo-Malaysia, Edisi revisi. Jakarta: PT. Gramedia Pustaka Utama.

19. Liubov, Arie Laor. Relationship between changes in neck circumference and cardiovascular risk factors. Exp Clin Cardiol. Vol 11, No 1. 2006.

20. Keaney JF, Larson MG, Vasan RS, Wilson PW, Lipinska I, Corey D, et al. Obesity and systemic oxidative stress clinical correlates of oxidative stress in the Framingham study. Arterioscler Thromb Vasc Biol 2003; 23(3): 434-439.

21. Preis SR, Pencina MJ, D'Aqoatino RB Sr, Meiqs JB, Vasan RS, Fox CS. Neck circumference and the development of cardiovascular disease risk factors in the Framingharm heart study. Diabetes Care 2013, 36:e3. 
22. Vander,A.J., Sherman, J.H. and Luciano, D.S.: Human Physiology, The Mechanism of Body Function. 1994. 648-651.

23. Jing-ya Zhou, et.al. Neck circumference as an independent predictive contributor to cardiometabolic syndrome. Cardiovascular Diabetology 2013, 12:76.

24. Darmawan, Hardi dan Irfanuddin. Effect of age and sex on the association between lipid profile and obesity among telecomunication workers in Palembang. Med J Indones. Vol 16, No 4. 2007.

25. Henry CJK. Mechanisms of changes in basal metabolism during ageing. Eur J Clin Nutr 2000, 54(3): S77-S91.

26. Askandar Tjokroprawiro. 2006. Hidup Sehat dan Bahagia bersama Diabetes Mellitus. Jakarta: Gramedia Pustaka Utama. p. 1-2.

27. Hilal Yildiran, Acar TN, Koksal E, Gezmen KM, Akbulut G, Bilici S, Sanlier N. The association of anthropometric measurements and lipid profiles in Turkish hypertensive adults. African Health Sciences Vol 11 No 3. 2011.

28. Payne, M. (1995). Kiat Menghindari Penyakit Jantung. Jakarta : Penerbit PT. Gramedia Pustaka Utama. p.15-17.

29. Department of Medicine. Dissertation. To Study the Relationship of Neck Circumference as a Parameter in Predicting Metabolic Syndrome - a one year cross sectional study. Jawaharlal Nehru Medical College, Belgaum, Karnataka. 2013.

30. LaBerge, Rbert C., J.P Vaccani \& R.M Gow . (2009). Inter and Intra Rater Reliability of Neck Circumference Measurements in Children. Pediatric Pulmonology Vol. 44: 64-69.

31. Aswathappa, Jagadamba, Sumit Garg, Karthiyanee Kutty, Vinutha Shankar. Neck circumference as an Anthropometric Measure of obesity in diabetics. North American Journal of Medical Sciences. 2013. Vol 5(1) : 28-31.

32. Suparjo HP. 2010. Hubungan Rasio Lingkar Pinggang Pinggul dengan Profil Lipid pada Pasien Penyakit Jantung Koroner (PJK) di Poliklinik Jantung RSUD dr. Moewardi Surakarta. Skripsi. Diterbitkan, Fakultas Ilmu Kesehatan Universitas Muhammadiyah, Surakarta.

33. Qun Yan et.al. Neck circumference is a valuable tool for identifying metabolic syndrome and obesity in Chinese elder subjects: a communitybased study. Diabetes Metab Res Rev 2014; 30: 69-76.

34. Jensen MD. Gender differences in regional fatty acid metabolism before and after meal ingestion. $J$ Clin Invest 1995; 96(5): 2297-2303.

35. Guo Z, Hensrud DD, Johnson CM, Jensen MD. Regional postprandial fatty acid metabolism in different obesity phenotypes. Diabetes 1999; 48(8): 1586-1592.

36. Nielsen S, Guo Z, Johnson CM, Hensrud DD, Jensen MD. Splanchnic lipolysis in human obesity, J Clin Invest 2004; 113(11): 1582-1588. 